DOI: https://doi.org/10.47405/mjssh.v5i8.472

\begin{tabular}{|c|c|}
\hline & Malaysian Journal of Social Sciences and Humanities (MJSSH) \\
\hline Malavsian Journal of & Volume 5, Issue 8, August 2020 \\
\hline (MJ - SSH) & e-ISSN : 2504-8562 \\
\hline & $\begin{array}{l}\text { Journal home page: } \\
\text { www.msocialsciences.com }\end{array}$ \\
\hline
\end{tabular}

\title{
Challenges Faced by Hearing Impairment Students During COVID-19
}

\author{
Isai Amutan Krishnan', Geraldine De Mello², Shelen Aderina Kok ${ }^{3}$, Saabdev Kumar Sabapathy", \\ Saravanan Munian5, Hee Sio Ching6, Pushpa Kandasamy ${ }^{7}$, Selvajothi Ramalingam ${ }^{1}$, Shasthrika \\ Baskaran $^{8}$, Vasudevan Naidu Kanan', \\ 1 Faculty of Languages and Linguistics, University of Malaya (UM) \\ ${ }^{2}$ Academy of Language Studies, Universiti Teknologi MARA (UiTM), Melaka \\ 3Faculty Psychology and Education, Universiti Malaysia Sabah (UMS) \\ ${ }^{4}$ Lecturer, Kuala Lumpur \\ 5SRJKT Ganesar Serdang, Kedah \\ 6ELM Business School, HELP University \\ ${ }^{7}$ SMK Dato' Bentara Dalam, Segamat, Johor \\ ${ }^{8}$ Wisma RnD, University of Malaya (UM) \\ ${ }^{9} \mathrm{O}^{\prime}$ Connor's Engineering Sdh. Bhd.
}

Correspondence: Isai Amutan Krishnan (amuthan.isai@gmail.com)

\begin{abstract}
Social distancing and other protocols required during the COVID-19 pandemic have been particularly difficult for students who are disabled, especially hearing impairments students. During the Covid-19, many disabled students were impacted physically, mentally and their interactions may have been hindered. That could be one of the barriers for full and active participation in society during the Covid19. Therefore, this study aims to discover the challenges faced by hearing impairment students how it affects the communication and mainstreaming process. The data was collected from ten hearing impairments students and analysed qualitatively. The participants were aged between 19-22 and currently studying foundation programme in culinary arts in a skill transformation center. The participants were interviewed using impromptu interview questions via WhatsApp, which lasted about ten minutes for each participant. The findings show that there were four challenges faced by the hearing impairment students; hearing devices, disruption to comprehend the lesson, not familiar with the online devices and emotionally affected during online classes. The findings further reveal that the hearing impairment students hampered their social interactions skills towards others during the pandemic. It is hoped the findings would be useful for academicians, counsellors, doctors and other job professions to explore further research on hearing impairments and the framing of methodology to assist the hearing impairments in engaging with the society during the pandemic.
\end{abstract}

Keywords: challenges, hearing impairment, Covid-19

\section{Introduction}

It can be contemplated that COVID-19 relates to various leverages of segregation for students with impairments because this pandemic happens to affect students indiscriminately. While the pandemic afflicts people irrespective of class, creed, religion, colour or country, it is humans who fabricate classes or barriers and constraints in the availability of capital and liberties. 
Malaysia Government has imposed an extreme measure to contain the deadly Covid-19 pandemic outbreak, and people were commended for staying at home and exercising social distancing. There are a group of people who have gone through some unexpected difficulties during the Covid-19, especially disable students.

In the very first time, humans have experienced a feeling of exclusion from ordinary life and a sense of isolation, according to the World Economic Forum (WEF) (Athira Nortajuddin, 2020). Nevertheless, for people with disabilities, the sense of isolation and daily experience of exclusion is nothing new and is considered a norm for many. It is estimated that $15 \%$ of the world's population has a disability. As huge populations are anxious and impatiently waiting for businesses to resume and for life to return to normal after the pandemic, this goes to the disabled students.

Referring to Higher Education Malaysia, there is an incomplete number of students with disabilities students (Islam, 2015). Nonetheless, Figure 1 shows the number of students with disabilities in Malaysian public universities.

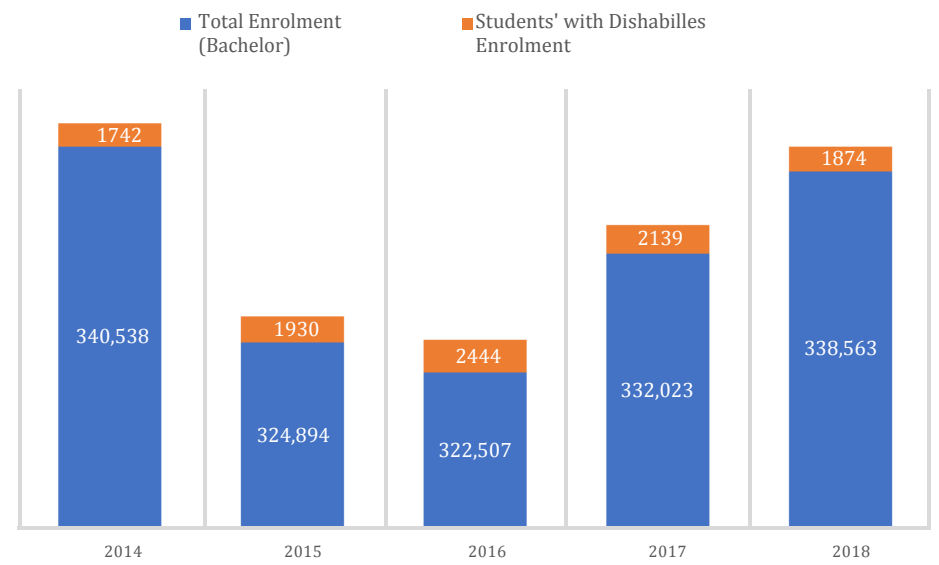

Figure 1: Number of undergraduate students' enrolment in public universities from 2014 to 2018 (MOE, 2014-2018)

In line with students with disabilities, Athira Nortajuddin (2020) reported that people with disabilities are among the world's most marginalised and stigmatised even under normal circumstances," said Jane Buchanan, deputy disability rights director at Human Rights Watch (HRW), see Figure 2.

\section{DISABILITY PREVALENCE IN SOUTHEAST ASIA}

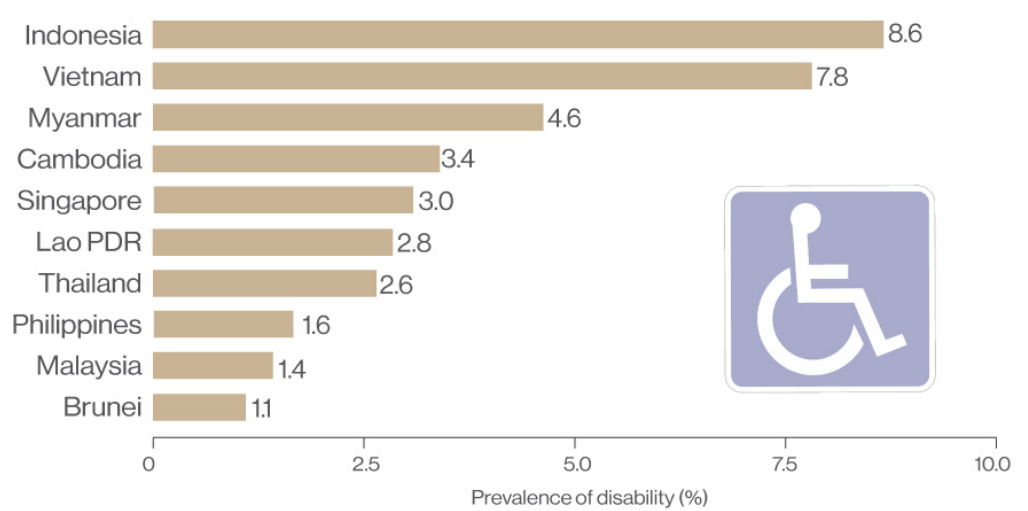

Figure 2: United Nations Economic and Social Commission for Asia and the Pacific (UN ESCAP) 
The organisation has urged governments to make extra efforts to protect the rights of people with disabilities when responding to the pandemic (Athira Nortajuddin, 2020). However, there were still some disabled students neglected, especially hearing-impaired students. This norm had impacted the disabled students thoroughly when a vital transition happened from face-to-face teaching to online learning.

According to Jamila (2005), special students differ in terms of characteristics of mental, sensory ability, communication skills, social behaviour and physical characteristics. Therefore, special consideration has to be given to these students to facilitate their learning to develop their full potential either a face-to-face teaching or an online class. This justifies the need to modify and customise teaching practices to cater to them. Chua and Koh (1992) defined students with special needs or exceptional students as students who have profound differences in terms of intelligence and communication or even in terms of feelings (Ramayah \& Sreedharam, 2020).

While, Garciulo (2003) and Menon (2019) defined students with special needs as individuals who differ from societal or community standards for normalcy. These differences may be due to significant physical, sensory, cognitive, or behavioural characteristics. Many of these students may require educational programs customised to their unique needs during the pandemic. Disabilities in learning are problems that affect the brain's ability to receive process, analyse, or store information when a transition happened from face-to-face teaching to online learning. These problems can make it difficult for students to learn as quickly as someone who is not affected by learning disabilities (Rayyan Rafidi, 2020).

Even students may have had physical disabilities or health problems. Students with physical disabilities have problems with the structure or the functioning of their bodies when transitions happened. Devraj and Samsilah Roslan (2006) identify students with special needs as students who need teaching and learning approaches that are different from regular students. Students with special needs students are divided into troubled eyesight, hearing problems and learning disabilities (Devraj \& Samsilah, 2006).

In the present study, students with special needs are those who have disabilities severe enough to give a profound effect on normal life, learning and cognitive development (Abdul Rahim, 2006). Meadow and Trybus (1985) reported a higher prevalence of Emotional/Behavior Disorder among deaf students. Characteristics which identifies an individual as having behavioural disorder are those that have little consideration of social or cultural norms during the pandemic. Therefore, the purpose of the study is to discover the challenges of imperfection students on hearing impairment and to show how it affects the communication and mainstreaming process during Covid-19.

\section{Literature Review}

The World Bank estimates that people with disabilities are the fifth of the world's poorest (World Bank, 2010). Disability begets Poverty. It is believed amongst people in developing countries that students with disabilities cannot learn or develop skills, so they are considered to be a burden. This situation has constrained opportunities for the disabled to participate in economic activities that can improve their quality of life. Segregation and marginalisation of disabled people believed to arise from the attitude of the environmental barriers restrict access to disabled people from full educational opportunity.

According to Persons with Disabilities Act of 2008, a disability includes those with long term physical, mental, intellectual or sensory impairments which in interaction with various barriers may hinder their full and active participation in society. Disability is thus, not just a health problem. It is a complex phenomenon, reflecting the interaction between features of a person's body and features of the society in which he or she lives. Overcoming the difficulties faced by people with disabilities requires interventions to remove environmental and social barriers; A person who is unable to decide for him to acquire the whole or part of the normal requirements in their life and social life cannot be entirely due to physical or mental and whether it occurs at birth or thereafter. 
There are disadvantages or the consequences of hearing impaired related to students' learning processes with hearing impairment. The level of education for students deafened in their infancy is less than those who lose their hearing in a different stage of their life. Their vocabulary and reading skills can really be affected for instance. The preferred learning style of students with hearing loss will generally be visual. It will be challenging for them to learn effectively if the message they receive is only expressed verbally. Technology such as FM systems can be a handy tool for them during the lecture (Chung, Subramaniam \& Christ, 2020). The impact of hard-of-hearing can be seen in terms of time. It takes a lot of time for students who require recorded information to receive it. This causes many problems to them as their self-esteem and confidence might go down.

\section{Past Studies}

Studies show that the three components: cognitive, affective and behaviourial represents the emotional portion of an attitude, whereas beliefs, ideas and opinions refer to the cognitive component. A person's willingness to interact with the subject at hand including the manner in which the do so best describes the behaviourial component. Attitudes consist of three mechanisms: emotional, cognitive, and behavioural (Olson \& Zanna, 1993). The emotional represents the affective part of an attitude, whereas the cognitive refers to thoughts, thinking, and views (Antonak \& Livneh, 1988). The behavioural describes a person 's keenness to interrelate with the matter which they do so (Cook, 1992).

In research relating to disability, the importance of understanding issues around the disabled is often under-appreciated. Considerable expertise is needed to address its issue and to help perhaps people understand more towards the disabled. As long as there is a negative attitude towards the disabled, people still cannot accept their presence, and the integration of disabled people in society will be closed (Yusmarhaini Yusof, Cheong, Azlin Hilma Hillaluddin, Fatimah Zailly Ahmad Ramli \& Zarina Mat Saad, 2019). Factors that can change negative attitudes towards disabled people are informed about the group and direct contact with them. More information about disabled people known to the community, the less negative stereotypes about the disabled and the more positive their attitude towards disabled people (Mathers, 2003) and similarly, direct contacts with disabled people improve their attitude towards disabled people.

Students with hearing loss can find the classroom a challenging environment and this can lead to social isolation. Not being able to interact with other students may affect the learning process. They are not motivated to take part in tutorials. If they cannot follow the progress of the lecturer, they might not learn effectively. As Doyle (2002) remarks that the importance of hearing is often underestimated mainly because, for the most part, it is an invisible disability. The lack of understanding of hearing loss is further compounded by the tendency to classify the ability to hear into two categories: hearing and deaf. There is a diversity of definitions of hearing impairment. Thus, comparison among studies is difficult. We use WHO classification that classified hearing impairment according to the pure tone average in the better hearing ear. Categories of hearing impairment range from "no impairment" to "profound impairment" according to the threshold level (Mathers, 2003). Based on the findings of Mohd. Sharani Ahmad (2004), a total of 24 of 141 students in four schools in the Klang Valley, Selangor was now wearing hearing aids. The examination results also found that $38.5 \%$ of hearing aid batteries are weak and produce a sound that is not clear. $35.9 \%$ of the students found mould their ear hearing aids are dirty and clogged. Pupils are very severe; hearing loss can hardly detect the sounds of the spoken speech but with the help of hearing aids. Attention and teaching methods on children's hearing is different from students with special needs and the other due to the difference in their problems and needs. Only 39 hearing aids used by the 24 students who participated in this study. Hearing aids do not work well when there are some problems such as the sounds are not clear; the battery is low, dirty and clogged ear mould and so on. The lack of knowledge by teachers and parents about hearing aids because they cannot repair the device in the event of damage. Not all types of damage to hearing aid to be sent to a specialist (Mohd. Sharani Ahmad, 2004). Based on the discussed literature reviews, it has been found that there are still lack of studies conducted on the challenges of hearing impaired students during Covid-19 pandemic. 


\section{Methodology}

\section{Setting}

The data was collected from MySkill Foundation, which is located in Klang Valley, Malaysia, and it is also known as MySkills Transformation Center. This institution provides skills courses such as culinary arts, electric and electronic and also courses on social or public awareness. The consent was obtained to conduct the research from the organisation as well as the participants. Due to ethical concerns, the identity of the participants was kept anonymous.

\section{Sampling}

There were ten students participated in this study. Seven females and three males. Among these 10 participants, three with the hearing aid device and the rest were not. They were in mid of obtaining the hearing aids as they are required several procedures. These participants were after SPM (Malaysian Certificate Examination), and their results were not favourable to enter any private colleges or universities to pursue their tertiary courses. They were moderately severe hearing loss, 56-70 hearing loss range (db HL). These participants were from a culinary arts course, and they were relying on reading, visual as well as spoken instructions to pursue the course.

\section{Data collection and Analysis Procedures}

The data was collected via impromptu interview questions via WhatsApp as all the students have refrained from the contacts during Covid-19 pandemic. The interviews were conducted into two sessions; the first interview was with five-participant, and the second was with another five-participant. There were no standard interview questions constructed. The questions were based on the objective of the study as Miles and Huberman (1994) noted that for an impromptu interview, a structured or a semistructured interview question may not necessary as the impromptu questions can be asked about the context and repeatedly asked until get the accurate information till meet the objective of the study.

\section{Analysis And Discussion}

The responses of the subjects were analysed to identify the challenges faced by hearing impaired students during Covid-19. Through interview following four challenges emerged and summarised from the ten students:

\section{Hearing devices}

'... hearing devices are unable to pick up speech or sounds completely and accurately during online lessons. Lip reading entails a great deal of focus and exertion. I always strive to comprehend the topic if there are no closed captions or subtitles during video conferencing. At times, presentation slides are not available in online classes also." Since universities were time constrained to make the necessary changes to courses on account of the pandemic, he recognized the shortcomings he and others were facing currently...'

\section{Disruption to comprehend the lesson}

'...there were three students who suffered from spastic diplegia, a form of cerebral palsy, opined that online education could benefit students with disabilities. Even so, they too faced problems in online learning. For those requiring additional help, having the online learning alternative would be useful. But for us, even though we are not very mobile, we favour face-to-face learning because it is more appealing and we able to intermingle with other students and lecturers. We are required to format questions digitally in place of voicing them to reduce disruptions. Since it 
affects my motor skills, it is a struggle to type fast enough. We are fortunate anyway, as we can still rely upon social media to bring up questions. It our opinion that raising questions orally should be an alternative for students with disabilities. The recording of all lectures would go a long way in assisting special needs students understand the relevant subjects better. Lecturers should be aware that students with disabilities must be provided with sufficient time to process the subjects being taught...'

\section{Not familiar with the online devices}

'...face difficulties learning through the online system. Normally we use my recording device and record the lectures in the class. Online learning requires devices that we are not familiar with, like the laptop and Smartphone. People mention about applications like Skype, Google Classroom, Zoom etc but we feel we are not able to use any of these. Our parents don't understand what online learning means and we can't afford to purchase a smartphone". Additionally, they stated, "it is not just an affordability matter but the fact that most of us require help in technology usage...'

\section{Emotionally Affected}

'...we are emotionally affected. How was thinking how the online class would be as I am disable student. I am not afforded to use expensive gadgets. This is really ruined us very much...'

The findings show that there were four challenges faced by the hearing impairment students; hearing devices, disruption to comprehend the lesson, not familiar with the online devices and emotionally affected during online classes.

The study aimed at identifying the challenges faced by hearing impairment students during Covid- 19 . The findings have found that no one can fight destiny determined over events occurring on earth by God. Every human is born like himself in the perfect condition physically, mentally, emotionally and socially. Then, you also have another set of humans who unfortunately are born with lesser means of livelihood; disabled to function aptly like the rest of us. Disabled students are looked upon as a burden, and not to become active contributors to the community and society at large.

Society should understand the special students that they have dreams and ambitions to be active in social, economic and political after they left school (Mohd. Sharani, 2004). Hajah Hasnah (1988) asserts that the early signs that may be available in students should be taken seriously and brought to see a physician to find out any deficiency in them.

The concern of the parents will be able to reduce the burden and reassure the students that belong to those with special needs to survive. Therefore, the community, especially parents, need advice, knowledge and assistance so that individual students can be appropriately guided during Covid-19 pandemic.

Signs that show that students who have hearing problems were not favour to online classes online classes, seems always to daydream, talking is not clear, was surprised when approached from behind, do not understand the instructions given and poor performance especially concerning language. Cognitive developments are a bit slow due to delays in language development. For social development, it depends on their experience, how the services were received, and through their development capabilities in online classes. 


\section{Implication of the Study}

This study carries a heavy weightage for parents when an abnormal symptom can be seen from a student during any types of pandemics. The impact could be seen when students' loss hearing while the consequences also could affect a students' future. Thus, teachers and parents play an important role in ensuring the students' auditory performance, educational achievements, spoken communication skills and quality of life during the pandemic. They consider the sensitivity of the privacy of the students in the case and the honour and dignity of the parents and family members. Being a case study, the findings may not be general and thus may not apply to the other cases with similar pandemics. Skillsbased colleges should provide necessary facilities for disabling, students, during the pandemic. Therefore, they are not hindered. This also should be monitored by the Higher learning intuitions that those skills-based colleges have specific facilities for disabled students. The main weakness of this study was the paucity of number of participants. It is good to have more participants to elicit more information on the challenges during the pandemic. This study was also limited by the absence of instructors to interview them to see what the challenges are they face to teach these hearing impairment students during the pandemic.

\section{Conclusion}

The present study can be concluded that by giving you some strategies that teachers and parents should follow to facilitate the learning of the deaf or hearing impaired during the pandemic. There are many ways to help teachers aid the students to learn to face the challenges, but some particular strategies exist to teach students to face challenges with hearing impairment during any pandemics. A teacher should always motivate this group physically and mentally and train them to face a challenge. Apart from the challenges, teachers make sure these students use the FM (frequency modulation) hearing systems if the online classes are equipped with them. Hearing aid microphone for the instructor. With such a microphone, the teacher can keep up with his way of speaking and teaching, but they should make sure that it is adjusted so that it lessens the background noise. Make sure the questions are wellcomprehended by students before answering them. Encourage the recording of your lectures. You can even copy your notes and distribute them to your students. Finally develop the reading skills of your students with hearing loss by encouraging them to read early before each class. Several questions still remain to be answered, further study can be looked at the communication skills. The study can be done by assigning an online role-play activity in a classroom to improve their communication skills, especially on the clarity, conciseness, completeness and correctness (Truman, 2011).

All institutions of higher learning must assign a special task force to facilitate students with impairments. The task force could recognise the prospective requirements of students and plan precise guidelines for faculty personnel in carrying out online learning, recorded lectures, mid-term tests, tasks and undertakings. There should be some leeway for students who cannot partake in an online study on account of some matters. Furthermore, universities must make sure of mental health assistance by affording health and safety policies, including managing anxiety that could result from maintaining social distancing. University counselling centers should provide online assistance to help students if the need arises. Other centers such as examination and admission centers can be improved with online capabilities for students with impairments in having access to results and registering for courses.

\section{References}

Athira Nortajuddin. (2020). Facing a pandemic with disabilities, THE ASEAN POST. Retrieved 7 August, 2020 from https://theaseanpost.com/article/facing-pandemic-disabilities

Abd. Rahim Talib. (2006). Introduction childhood education learning. Kuala Lumpur. MeteorDoc. PT. Ltd.

Abu Bakar Nordin \& Ikhsan Othman. (2003). Education philosophy and curriculum. Kuala Lumpur. Quantum Books. 
Burden of Disease. (2002). Data sources, methods and results. GPE Discussion Paper. Children's Disability Report, No. 54. 2003. World Health Organisation, Geneva.

Chung, E., Subramaniam,G. \&Christ,D.L. (2020). Online Learning Readiness Among University Students in Malaysia Amidst Covid-19. Asian Journal of University Education, 16(2), 47-58.

Chua, T. T. \& Kohm, B, B. (1992). Special education and rehabilitation. Kuala Lumpur. Oxford University Press.

Creswell, J. (2018). Research design: Qualitative, quantitative, and mixed methods approaches (5th ed.) SAGE Publications, Inc.

Devaraj,S. \& Samsilah Roslan. (2006). Apa itu disleksia. Kuala Lumpur. PTS Professional Publishing Sdn. Bhd.

Disability Statistics Annual Report. (2017). Rehabilitation research and training center on disability statistics and demographics, Institute on Disability/UCED, University of New Hampshire

Doyle. (2002). Cyberpsychology and behavior. Retrieved 05 August, 2020, from http://www.columbia.edu/ jc3700/pubs/cook,doyle(2002).pdf

Garciulo. (2003). Curriculum access for students with low-incidence disabilities. Retrieved 05 August, 2020 from http://aem.cast.org/about/publications/2005/ncac-curriculum-access-low-incidenceudl.html

Garciulo,R.M .(2003). Special education in contemporary society: An introduction to exceptionality. United State. Wadsworth Thomson Learning.

Hajah Hasnah \& Hjh Aishah Hj Udin. Jaafar .(1992). Guidance exceptional children. Kuala Lumpur: DBP / Ministry of Education Malaysia.

Hajah Hasnah Udin. (1988). Guidance exceptional children. Kuala Lumpur. Oxford University Press.

Jamila Mohamed K.A. (2005). Special Education for Students with Special Needs. Kuala Lumpur. PTS Publiction \& Distributions Sdn. Ltd.

Islam, M. Rezaul. (2015). Rights of the People with Disabilities and Social Exclusion in Malaysia. International Journal of Social Science and Humanity 5(3), 299-305.

Li, Moore \& Dennis. (1998). Acceptance of disability and its correlates. Journal of Social Psychology, $138(1), 13-26$.

Meadow, P. K., \& Trybus, J. R. (1985). Behavioural and emotional problems of deaf children: An overview. In L. J. Bradford \& W. G. Hardy (Eds.), Hearing and hearing impairment (pp. 395415). New York: Grune \& Stratton.

Melanie, D. (2002). Mainstreaming the student who is Deaf or hard-of-hearing. Director of CCHAT Center, San Diego.

Menon, S. (2019). Plans for special needs students. The Star. https://www.thestar.com.my/news/education/2019/01/06/plans-for-special-needs-students/

Messe (2001). HBS1 103 Identity Module Childhood Education Learning. Open University Malaysia.

Mohd. Salleh Lebar. (1999). problems of teaching and learning special needs children in the hearing. Serdang. Prince University of Malaysia.

Mohd. Sharani Ahmad. (2004). Managing difficult children learn. Kuala Lumpur. PTS Publications \& Distributors Sdn. Ltd.

Prado, D. F. (1991). A guide and handbooks for parents of mentally retarded children. Illinois. Charles C Thompson.

Rayyan Rafidi. (2020). Special needs students face hurdles in e-learning. New Straits Times. https://www.nst.com.my/education/2020/05/590453/special-needs-students-face-hurdles-elearning

Ramayah, B. \& Sreedharam, R. K. (2020). Voting experiences of visual impaired citizens during polling day in Malaysia. Malaysian Journal of Social Sciences and Humanities (MJSSH), 5(7), $1-6$.

Ross. (1993). Identity module hbs 1103 childhood education learning. Open University Malaysia.

Truman, H. S. (2011). Management study of communication skills. Journal of Human Resource, 1(3), 11-32.

Safe \& Kassim Mohamad Abd. Majid .(2003). Care and early childhood education (Form 4). Selangor. Level Mega (M) Sdn. Ltd.

Salt, A.N \& Hirose.K. (2018). Communication pathways to and from the inner ear and their contributions to drug delivery, Hearing Research, 1(2), 1-2.

Yusmarhaini Yusof, Cheong,C.C,. Azlin Hilma Hillaluddin, Fatimah Zailly Ahmad Ramli \& 
DOI: https://doi.org/10.47405/mjssh.v5i8.472

Zarina Mat Saad. (2019). Improving inclusion of students with disabilities In Malaysian higher education, Disability \& Society, 1-26.

\section{Authors' Details}

1. Isai Amutan Krishnan is currently doing his $\mathrm{PhD}$ at the Faculty of Languages and Linguistics, University of Malaya (UM), and his area of interests are in human resource development \& management, ELT, and performing arts. He is also a freelance consultant locally and abroad.

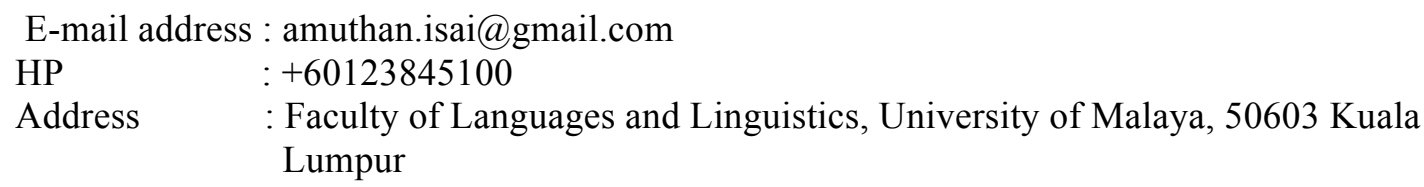

2. Geraldine De Mello, $\mathrm{PhD}$, is an Associate Professor at the Academy of Language Studies, Universiti Teknologi MARA Melaka. She has taught a number of English courses at the diploma and degree levels. She is actively involved in writing and has written several books. Some of her research articles have also been published in local and international indexed journals. She is also keen in innovating and producing educational tools to help educators teach in a fun way and creating a positive atmosphere among the students in the classrooms.

E-mail address : geraldine@uitm.edu.my

HP : $\quad$ : 60123736259

Address : Jabatan Bahasa Inggeris, Akademi Pengajian Bahasa, UiTM Cawangan Melakan Kampus Alor Gajah. Melaka.

3. Shelen Aderina Kok works in Co-Curricular Unit, Teacher Education Institution, Kent Campus. Presently, she is pursuing a $\mathrm{PhD}$ at the Faculty Psychology and Education, University of Malaysia Sabah. Her teaching experience includes teaching of various English Proficiency courses at schools and university levels. She is also currently involved in teaching TESL courses undergraduates' levels. Her research interests include pedagogical practices, teacher education and digital innovation.

E-mail address: shelenadekok@ipgm.edu.my, shelenadekok@yahoo.com

HP : : +60138512170

Address $\quad$ : PG Kampus Kent Peti Surat 289207 Tuaran, Sabah

4. Mr. Saabdev Kumar Sabapathy has a Masters in Education (TESL) and Bachelors in Education (TESL) from University Putra Malaysia. He is currently a lecturer at one of the universities in Kuala Lumpur. He has presented papers at international conferences. His areas of interest include English for Specific Purposes (ESP), Business Communication, Sociolinguistics and Psycholinguistics, Professional development, Literature in ESL and Indian Literature.

Email address : shaadev@gmail.com

HP : +60126227596

5. Saravanan Munian obtained his degree in Indian Studies from University of Malaya in 2008. He also obtained Diploma in Education from Teachers' Training Institute. He is currently a teacher in SRJKT Ganesar Serdang, Kedah. He is also interested in research in innovative, teaching and learning. Apart from teaching, he involves in corporate social responsibility.

Email address : dr.saravananshiva@gmail.com

HP : : +60195529186 
6. Ms. Hee Sio Ching obtained her Masters in ESL from UM and is currently a trainer who specialises in English at the workplace, offering presentation \& communication skill courses. She is also a part-time lecturer with HELP university where she explores students into the field of communication, writing skills, personal branding \& career Management, ESP as well as language in public relation.

E-mail address : ansiehee@hotmail.com

HP : $\quad$ :60133368175

Address : ELM Business School, HELP University, Jalan Sri Semantan 1, Off Jalan Semantan, Bukit Damansara, 50490 Kuala Lumpur

7. Pushpa Kandasamy is currently a secondary school English teacher in the State of Johor, Malaysia. She has been attached to the field of education (Ministry of Education, Malaysia) for 22 years and was awarded for her excellent service and contributions in this field thrice. She has also been appointed as the Excellent Teacher in the year 2017 by the Board of Federal Inspectors of Excellent Teacher Award. She has showcased her innovation during MELTA Conference besides presenting her innovations and was blessed with a few championship awards in the district and state level. She obtained her Master's Degree in The University of Malaya in 2015 and currently working as a teacher besides holding the post of Master Trainer for the district and state level programmes.

E-mail address : puvee2410@yahoo.com,

HP : : $\quad$ : $\quad$ : 19919610

Address : SMK Dato’ Bentara Dalam, KM 3 Jalan Genuang, 85000 Segamat Johor.

8. Selvajothi Ramalingam (PhD) joined as a senior lecturer in the Faculty of Languages and Linguistics at the University of Malaya (Department of Malaysian Languages and Applied Linguistics) in 2018. Before he joined the faculty, he was a teacher in secondary school and assistant director in Ministry of Education. He completed his Doctoral program in Sociolinguistics, Masters of Modern Languages Studies, and Bachelor of Arts at University Malaya. He also obtained a Diploma in Education and a Diploma in Translation. His main research interests are Sociolinguistics, Applied Linguistics in general, Tamil Linguistics, and Teaching Tamil Language in particular. Areas of particular interest include Language Shift and Maintenance, Ethnolinguistics, Language and Identity, Language and Culture, Minority languages, Mother tongue education, and Translanguaging.

E-mail address : selvajothi@um.edu.my

HP : : +60192267579

Address : Faculty of Languages and Linguistics, University of Malaya, 50603 Kuala Lumpur

9. Shasthrika Baskaran obtained her Master's in Educational TESL from University Putra Malaysia and she is currently a lecturer who specialises in teaching English Proficiency for students of University of Malaya. She also specialises in presentation \& communication skills courses. She is also a part-time lecturer at a private university where she offers courses in critical thinking skills.

E-mail address : shasthrika@gmail.com

HP : +60167961583

Address : Wisma RnD University of Malaya, Jalan Pantai Baharu, Taman Bukit Pantai, 59100 Kuala Lumpur, Wilayah Persekutuan Kuala Lumpur. 
10. Mr. Vasudevan Naidu Kanan is currently a Project Manager in the Business Communication Department of O'Connor's Engineering Sdn. Bhd, Kuala Lumpur. He did his Masters in Global Business from SEGI University Kota Damansara. He used to work in CIMB Group from the department of Client Management. His research interest is in social sciences, business and information technology.

E-mail address: evanleo05@gmail.com

HP : : +60129790535

Address : O'Connor's Engineering Sdn. Bhd. Bagunan O'Connor No.13 Jalan 223, 46100 Petaling Jaya, Selangor. 